\title{
Carbon Dioxide-induced Flesh Browning in Pink Lady Apples
}

\author{
Elena de Castro, Bill Biasi, and Elizabeth Mitcham ${ }^{1}$ \\ Department of Plant Sciences, University of California MS2, One Shields Ave. Davis, CA 95616-8780 \\ Stuart Tustin \\ HortResearch, Hawke's Bay Research Centre, Private Bag 1401, Havelock North, New Zealand
}

David Tanner

Food Science Australia, P.O. Box 52, North Ryde, NSW 1670, Australia

\author{
Jennifer Jobling \\ Agriculture Food and Natural Resources, University of Sydney, Sydney, NSW 2006, Australia
}

\begin{abstract}
Additional INDEX words: $\mathrm{CO}_{2}$-injury, Cripps Pink, delayed CA, diphenylamine, DPA, Malus Xsylvestris var. domestica, 1-methylcyclopropane, mineral composition, temperature

AbSTRaCt. To investigate a flesh browning (FB) disorder in Pink Lady apple [Malus $\times$ sylvestris (L.) Mill. var. domestica (Borkh.) Mansf. cv. Cripps Pink], fruit were harvested from the same orchard each year from 2002 to 2005, at two or three maturity stages each year. Fruit were kept in air or controlled atmosphere (CA) storage (1.5- to 2-kPa $\mathrm{O}_{2}$ in combination with 1-, 3-, or 5-kPa $\mathrm{CO}_{2}$ ) at $0.5{ }^{\circ} \mathrm{C}$. Additional subsets of fruit were exposed to $1 \mu \mathrm{L} \cdot \mathrm{L}^{-1}$ 1-methylcyclopropane (1-MCP) for 24 hours and dipped in $2200 \mu \mathrm{L} \cdot \mathrm{L}^{-1}$ diphenylamine (DPA) for 5 min or held in air at $0.5{ }^{\circ} \mathrm{C}$ for 2 or 4 weeks before $\mathrm{CA}$ storage. Flesh browning was not seen in air-stored fruit but appeared in CA-stored fruit as soon as 2 months after harvest. Flesh browning incidence did not increase after longer storage times. Flesh browning increased with increasing $\mathrm{CO}_{2}$ concentration and decreasing $\mathrm{O}_{2}$ concentration in storage. 1-MCP did not significantly affect FB incidence, while delaying CA by 2 or 4 weeks reduced it. Diphenylamine eliminated FB incidence. When similar storage atmospheres were compared for the four seasons, FB incidence was high in 2002 and 2004 and low in 2003 and 2005. Concentrations of B, Ca, and $\mathrm{Mg}$ in apple flesh and seasonal field temperatures during the growing and harvest periods were related to FB incidence in 2002, 2003, and 2004 but not in 2005. The relationship of these pre- and postharvest factors to FB susceptibility are discussed.
\end{abstract}

The Pink Lady apple ('Cripps Pink' apples of an appropriate quality and maturity may be sold using the brand name Pink Lady, a trademark of Apple \& Pear Australia Ltd., Victoria, Australia) was developed in Australia in the late 1960s from a cross between 'Golden Delicious' and 'Lady Williams.' Since then, it has been sought for its sweet-tart flavor and crunchy texture. However, in recent years Pink Lady apples have shown a susceptibility to developing internal browning in storage.

Controlled atmosphere (CA) storage extends the life and preserves the quality of Pink Lady apples (Cripps et al., 1993). However, CA can also induce expression of physiological disorders in susceptible apples, such as internal flesh browning in 'Fuji' apples (Volz et al., 1998) and Braeburn browning disorder (BBD) (Elgar et al., 1998; Lau, 1998). Flesh browning in apples occurs intermittently and in unpredictable patterns, perhaps due to the interaction of yet-to-be-identified pre- and postharvest factors that affect the physiological state of the fruit at harvest and resistance to postharvest stresses. There are at least three different manifestations of this physiological disorder. One is diffuse FB, which appears to be related to chilling injury (CI) (Bramlage and Meir, 1990); the second is radial browning, which is related to senescent breakdown (Wilkinson and Fidler, 1973); and the third is $\mathrm{CO}_{2}$ injury (brown spots

Received for publication 20 Sept. 2006. Accepted for publication 1 May 2007. The authors thank Tim Sambado of A. Sambado \& Sons (Linden, CA) for partial support of this project.

${ }^{1}$ Corresponding author. E-mail: ejmitcham@ucdavis.edu. that may develop into cavities), which is associated with CA storage (Lau, 1998).

Several factors predispose apple fruit to postharvest storage disorders. Variations in mineral composition are widely recognized to affect fruit quality after harvest (Bramlage et al., 1980; Sharples, 1980). Mineral composition greatly influences postharvest quality retention, and calcium is dominant in this respect. Trees high in nitrogen are usually vigorous trees with low crop loads; as a consequence, fruit is large, high in nitrogen, and low in calcium. Boron has a role in the structure of the plasma membrane (Parr and Loughman, 1983), and calcium is important in all cell membranes to stabilize phospholipids (Marinos, 1962).

Climate after full bloom and before harvest can have a great effect on postharvest development of physiological disorders (de Villiers, 1961; Warrington et al., 1999). Lau (1998) assessed the relationship between the incidence of BBD and cumulative growing degree days higher than $10^{\circ} \mathrm{C}$ from 1 May to harvest. Lau (1998) concluded that a cool growing season could increase the susceptibility of the apple to $\mathrm{CO}_{2}$ injury. Other weather effects are more related with harvest time. Light intensity and other developmental and environmental factors can significantly affect the concentration of sugars and ascorbic acid as well as fruit size (Kondo, 1992).

Fruit maturity has been demonstrated to be a factor in susceptibility to internal browning in some apple cultivars (Lau, 1998; Volz et al., 1998). In addition, diphenylamine, an antioxidant used commercially to inhibit storage scald in 
apples (Lau, 1990), markedly reduced both external and internal browning from $\mathrm{CO}_{2}$ injuries in some apple cultivars (Fernández-Trujillo et al., 2001; Watkins et al., 1997). Delaying the establishment of $\mathrm{CA}$ has also been shown to reduce internal browning (Argenta et al., 2000).

Our objectives were to determine the most important preand postharvest factors that affect the susceptibility of Pink Lady apples to develop $\mathrm{CO}_{2}$-induced internal FB and investigate possible solutions.

\section{Materials and Methods}

Fruit Material. On 21 Sept. and 20 Oct. 2002; 6 and 20 Oct. and 6 Nov. 2003; 21 Sept. and 5 and 22 Oct. 2004; and 29 Sept. and 15 Oct. 2005, Pink Lady apples were harvested in the early morning from five 40-tree plots in the same orchard near Stockton, CA. About 50 apples were harvested randomly per tree, and each tree was harvested once. For every harvest, the apples were selected according to average background color and size for that tree and harvest date. Apples were harvested from the middle of the canopy from top to bottom and trunk to exterior.

QuAlity AND INTERNAL BRowning EVALUATIOn. On the day of harvest, 30 fruit were selected randomly among the five plots to determine firmness and starch pattern index. Firmness was measured as resistance to penetration with an 11-mm flat-ended cylindrical probe on opposite sides of the fruit using a fruit texture analyzer (Güss Manufacturing, Strand, South Africa) after removing a small area of peel with a regular skin peeler. The apples were then cut in half equatorially, dipped for $2 \mathrm{~min}$ in iodine/potassium iodide $(3 \%)$, and rinsed in fresh water. Starch levels were scored using a Center Technique Interprofessionnel des Fruits et Legumes (CTIFL, Paris) 10-point scale. When FB was evaluated after storage, 80, 105, 125, and 125 fruit per treatment in 2002, 2003, 2004, and 2005, respectively, were cut equatorially in three equally spaced locations resulting in $\approx 2$-cm-thick slices, and the presence of FB was visually determined.

Treatments. Fruit were kept at $10{ }^{\circ} \mathrm{C}$ overnight before being sorted to obtain undamaged fruit of uniform size and color among the fruit in each plot before random assignment to the treatments, and the same number of fruit per plot was assigned to each treatment. Immediately after they were sorted, fruit were cooled to $0.5{ }^{\circ} \mathrm{C}$ in air for $24 \mathrm{~h}$ before the CA treatment was started. Following a determined storage period plus $5 \mathrm{~d}$ at $20^{\circ} \mathrm{C}$, fruit were assessed for FB, firmness, and other quality attributes, as described above.

Harvest dates each year were determined by the fruit's CTIFL starch index values: harvest $1, \approx 3.5$; harvest $2, \approx 6.0$; and harvest $3, \approx 8.5$. The CA storage conditions varied between years (Table 1). In 2002, apples were stored in air or in 1.5-, $3.0-$, or $21-\mathrm{kPa} \mathrm{O}_{2}$ in a factorial design with 1.0-, 3.0-, and $5.0-\mathrm{kPa} \mathrm{CO}_{2}$. In 2003, fruit were stored in air or in $2-\mathrm{kPa} \mathrm{O}_{2}$ in a factorial design with $1-$ and $3-\mathrm{kPa} \mathrm{CO}_{2}$. In 2004, fruit were stored in air or 1.5- $\mathrm{kPa} \mathrm{O}_{2}$ in a factorial design with 1.0-, 3.0-, and $5.0-\mathrm{kPa} \mathrm{CO}_{2}$ and in 2005 , fruit were stored in air or $1.5-\mathrm{kPa}$ $\mathrm{O}_{2}+5.0-\mathrm{kPa} \mathrm{CO}_{2}$. The storage temperature was always $0.5^{\circ} \mathrm{C}$, and the storage time varied between 2 and 6 months.

Additional apples from the second harvest in 2003 were precooled at $0.5^{\circ} \mathrm{C}$ and placed into $300-\mathrm{L}$ steel tanks for $1-\mathrm{MCP}$ treatment. A small electric fan was placed inside each tank to ensure even distribution of 1-MCP gas around the fruit. The
Table 1. Starch index values at harvest for Pink Lady apples under CA conditions and additional treatments applied in each season from 2002 to 2005 .

\begin{tabular}{|c|c|c|c|c|}
\hline \multirow[b]{3}{*}{ Season } & \multicolumn{4}{|c|}{ Storage conditions and treatments } \\
\hline & \multirow{2}{*}{$\begin{array}{c}\text { Harvest } \\
\text { maturity } \\
\text { Starch index }\end{array}$} & \multicolumn{2}{|c|}{$\begin{array}{c}\text { Controlled } \\
\text { atmosphere }(\mathrm{kPa})\end{array}$} & \multirow{2}{*}{$\begin{array}{l}\text { Additional } \\
\text { treatments }\end{array}$} \\
\hline & & $\mathrm{O}_{2}$ & $\mathrm{CO}_{2}$ & \\
\hline \multirow[t]{16}{*}{2002} & 3.5 & 1.5 & 1 & \\
\hline & & & 3 & \\
\hline & & & 5 & \\
\hline & & 3 & 1 & \\
\hline & & & 3 & \\
\hline & & & 5 & \\
\hline & & 20 & 1 & \\
\hline & & & 3 & \\
\hline & & & 5 & \\
\hline & 6.0 & 1.5 & 1 & \\
\hline & & & 3 & \\
\hline & & & 5 & \\
\hline & & 3 & 1 & \\
\hline & & & 3 & \\
\hline & & & 5 & \\
\hline & & 20 & 3 & \\
\hline \multirow[t]{6}{*}{2003} & 3.5 & 2 & 1 & \\
\hline & & & 3 & \\
\hline & 6.0 & 2 & 1 & $1-\mathrm{MCP}^{\mathrm{y}}, \mathrm{DPA}^{\mathrm{x}}$ \\
\hline & & & 3 & 1-MCP, DPA \\
\hline & 8.5 & 2 & 1 & Delayed $\mathrm{CA}^{\mathrm{w}}$ \\
\hline & & & 3 & Delayed CA \\
\hline \multirow[t]{9}{*}{2004} & 3.5 & 1.5 & 1 & \\
\hline & & & 3 & \\
\hline & & & 5 & \\
\hline & 6.0 & 1.5 & 1 & DPA \\
\hline & & & 3 & DPA \\
\hline & & & 5 & DPA \\
\hline & 8.5 & 1.5 & 1 & Delayed CA \\
\hline & & & 3 & Delayed CA \\
\hline & & & 5 & Delayed CA \\
\hline \multirow[t]{3}{*}{2005} & 3.5 & 1.5 & 5 & DPA \\
\hline & 6.0 & 1.5 & 5 & \\
\hline & 8.5 & 1.5 & 5 & \\
\hline
\end{tabular}

${ }^{\mathrm{z}}$ Starch index at harvest (CTIFL scale, $\left.1-10\right)$.

${ }^{\mathrm{y}} 1 \mu \mathrm{L} \cdot \mathrm{L}^{-1} 1$-methylcyclopropane (1-MCP).

${ }^{\mathrm{x}} 2200 \mu \mathrm{L} \cdot \mathrm{L}^{-1}$ diphenylamine (DPA).

w2 or 4 weeks in air at $0.5^{\circ} \mathrm{C}$ after harvest before CA storage.

tank lids were constructed to fit into water-filled troughs, forming a hermetic seal. Smart Fresh (AgroFresh, Springhouse, PA) tablets were used to generate $1 \mu \mathrm{L} \cdot \mathrm{L}^{-1}$ of $1-\mathrm{MCP}$ gas in the tank. Apples were treated with 1-MCP for $24 \mathrm{~h}$ at $0.5^{\circ} \mathrm{C}$ and then transferred to air or $\mathrm{CA}$ at $0.5^{\circ} \mathrm{C}$. A second set of fruit from the same harvest in 2003, and additional fruit from the second and first harvests in 2004 and 2005, respectively, were treated with $2200 \mu \mathrm{L} \cdot \mathrm{L}^{-1} \mathrm{DPA}$ in water by immersion for $5 \mathrm{~min}$, airdried at $20^{\circ} \mathrm{C}$, and precooled overnight at $0.5^{\circ} \mathrm{C}$ before storage in air or CA at $0.5^{\circ} \mathrm{C}$. Additional fruit from the same (2005) or another harvest (2003 and 2004) were placed into CA storage after 2 or 4 weeks' delay in air at $0.5^{\circ} \mathrm{C}$. Fruit were then stored for 4 months. 
DENSITY. Density of apples was calculated every season from 2002 to 2004 using fruit of intermediate maturity (CTIFL starch score, $\approx 6.0$ ) after 3 months of storage in air at $0.5^{\circ} \mathrm{C}$. Five fruit were selected, one from each plot in the orchard, and weight and buoyancy was recorded. Buoyancy was measured by immersing the apple under water and recording the force exerted by the apple to return to the water surface. The apple was submerged under a metallic funnel with hemispheric shape to hold the apple under the water without forming air bubbles. The funnel was attached with a hard wire to the hook of the bottom of the balance, and the force (grams) was recorded. To calculate the density from the weight and the buoyancy, we used the following formula:

$$
\delta(\text { density })=(\text { weight }- \text { buoyancy }) / \text { weight. }
$$

Mineral anAlysis. Apples of average background, color, and size were selected from each plot. Tissue samples consisted of two unpeeled wedges from each of a total of 25 apples each year, five fruit per five orchard plots. The wedges were chopped and a sample of $\approx 1 \mathrm{~g}$ was collected, including some skin, and mixed with the other apple samples so that $\approx 5 \mathrm{~g}$ from each of the five plots was collected for analysis. The samples were dried at $90{ }^{\circ} \mathrm{C}$ for $48 \mathrm{~h}$, heated at $500{ }^{\circ} \mathrm{C}$ for $4 \mathrm{~h}$, and dissolved in $1 \mathrm{~N}$ nitric acid. All samples were sent to a laboratory for analysis [University of California (UC), Division of Agriculture and Natural Resources Analytical Laboratory, Davis, CA]. Samples were analyzed for $\mathrm{Ca}, \mathrm{B}$, and $\mathrm{Mg}$ by inductively coupled plasma atomic emission spectrometry (ICP-AES) as described by Meyer and Keliher (1992) and by atomic emission spectrometry (AES) for K.

Individual apple mineral composition was also measured in healthy tissue of fruit with and without $\mathrm{FB}$ after storage in 1.5-kPa O $\mathrm{O}_{2}+5-\mathrm{kPa} \mathrm{CO}_{2}$ for 2, 4, and 6 months in 2004 and 2 and 4 months in 2005. A total of 30 apples were analyzed each year. After each storage time, apples were selected, one half with FB and one half without. Samples were freeze-dried and sent to a laboratory for analysis as previously described.

Weather DATA. The weather data were collected from a weather station very near the orchard in Farmington, CA (UC Statewide Integrated Pest Management Program, Davis, CA). The average daily air temperature was recorded for the $50 \mathrm{~d}$ after full bloom (DAFB), beginning on 4, 7, 21, and 17 March for 2002, 2003, 2004, and 2005, respectively.

To calculate the growing degree days (GDD) $\geq 10^{\circ} \mathrm{C}$ during one period, the base of the calculation (10) was subtracted from the daily average temperature for every day of that period. The positive remainders were added to calculate the cumulative growing degree days $(\mathrm{CGDD}) \geq 10{ }^{\circ} \mathrm{C}$. To calculate the lowtemperature exposure during the 50 DAFB [cumulative degree days (CDD) $<10^{\circ} \mathrm{C}$ ], the base of the calculation (10) was subtracted from the daily temperature average for every day of that period, and the negative remainders were added to obtain the total low-temperature exposure.

Statistical analysis. The experimental design consisted of two or three harvest maturities, storage time ( 2 or 4 or 6 months), and treatment (atmosphere, DPA, 1-MCP, and delayed CA). Each year was analyzed separately by harvest date and time in storage, and a factorial design was employed with five repetitions of $16,21,25$, and 25 individual fruit each consecutive year. Analysis of variance was computed by SAS (version 8.02; SAS Institute, Cary, NC). Least-square means were employed due to missing values in some treatments. Multiple mean comparisons were performed using TukeyKramer adjustment, which was necessary due to the large number of mean comparisons required and the need to maintain a low experimental error rate $(\alpha=0.05)$.

\section{Results}

High-CO - AND LOW-O - - RELATED INJURY. In 2002, the incidence of fruit with $\mathrm{FB}$ increased with greater $\mathrm{CO}_{2}$ and with lower $\mathrm{O}_{2}$ concentrations during storage (Fig. 1; Table 2). The

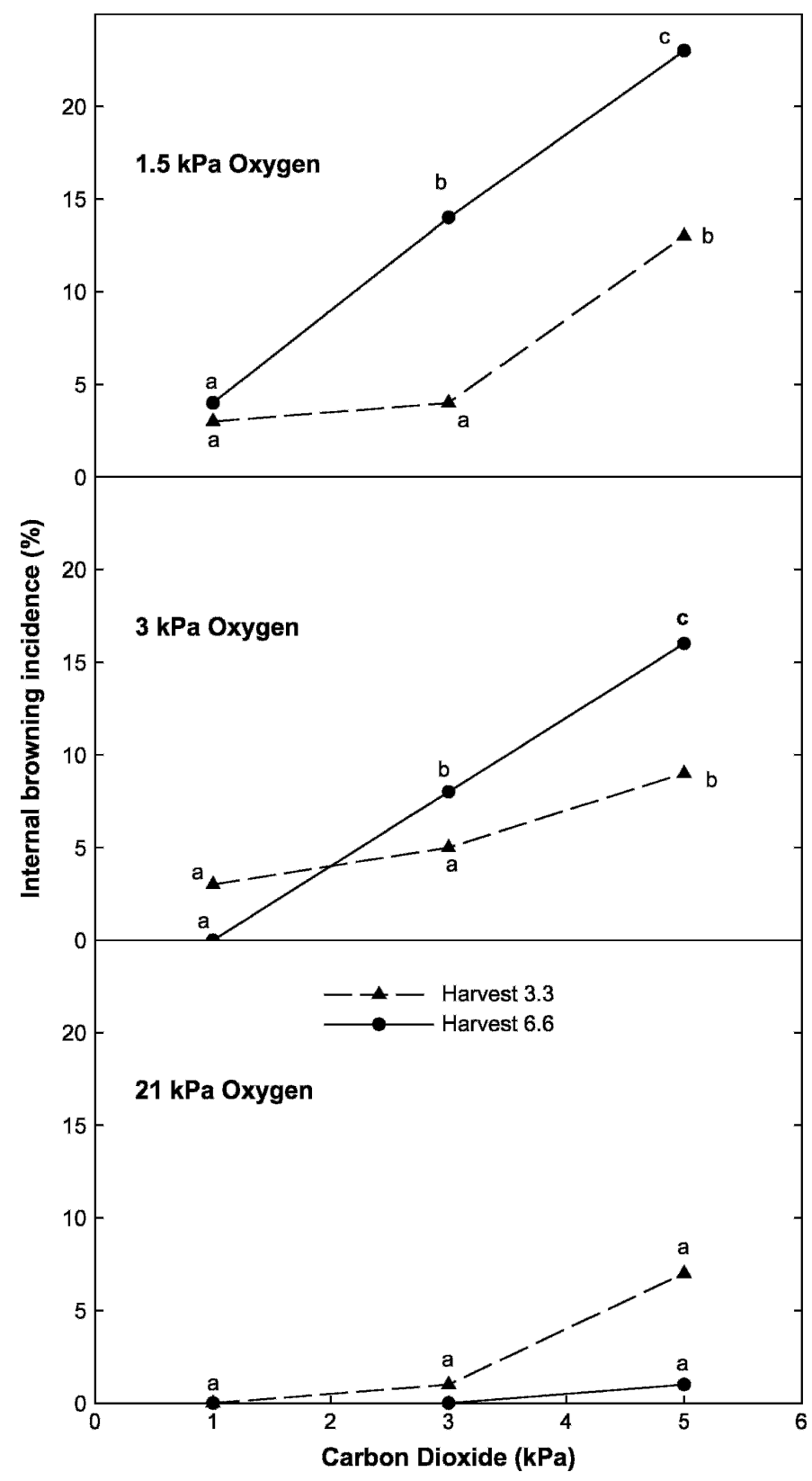

Fig. 1. Relationship between the incidence of flesh browning after 2 months of storage at $0.5^{\circ} \mathrm{C}$ in apples harvested at two maturities (starch indices of 3.5 and 6.5) in 2002 and the concentrations of $\mathrm{CO}_{2}$ and $\mathrm{O}_{2}$ in storage. Different letters within an $\mathrm{O}_{2}$ concentration indicate significant differences $(P \leq 0.05)$ according to Tukey's test. 
Table 2. Influence of season, fruit maturity, CA conditions, tree crop load, and average fruit size on the incidence of flesh browning in Pink Lady apples after 2 mo. of storage.

\begin{tabular}{|c|c|c|c|c|c|c|c|}
\hline \multirow[b]{3}{*}{ Season } & \multirow{3}{*}{$\begin{array}{c}\text { Harvest maturity } \\
\text { Starch index }\end{array}$} & & & \multicolumn{2}{|c|}{ Season characteristics } & \multicolumn{2}{|c|}{ Flesh browning } \\
\hline & & \multicolumn{2}{|c|}{ Controlled atmosphere } & \multirow{2}{*}{$\begin{array}{l}\text { Crop load } \\
\left(\mathrm{kg} \cdot \mathrm{ha}^{-1}\right)^{\mathrm{z}}\end{array}$} & \multirow{2}{*}{$\begin{array}{l}\text { Avg fruit } \\
\text { wt (g) }\end{array}$} & \multirow{2}{*}{$\begin{array}{l}\text { Flesh browning } \\
\text { incidence }(\%)\end{array}$} & \multirow{2}{*}{$\begin{array}{c}\text { "Relative" flesh } \\
\text { browning }\end{array}$} \\
\hline & & $\mathrm{O}_{2}(\mathrm{kPa})$ & $\mathrm{CO}_{2}(\mathrm{kPa})$ & & & & \\
\hline \multirow[t]{4}{*}{2002} & 3.5 & 1.5 & 1 & 36,313 & 173 & 3 & High \\
\hline & & & 5 & & & 13 & \\
\hline & 6 & 1.5 & 1 & & & 4 & \\
\hline & & & 3 & & & 14 & \\
\hline \multirow[t]{5}{*}{2003} & 3.5 & 2 & 1 & 29,357 & 183 & 2.5 & Low \\
\hline & & & 3 & & & 2.5 & \\
\hline & 6 & 2 & 1 & & & 1.3 & \\
\hline & & & 3 & & & 1.3 & \\
\hline & 8.5 & 2 & 1 & & & 0,0 & \\
\hline \multirow{7}{*}{2004} & & & 5 & & & 32 & \\
\hline & 6 & 1.5 & 1 & & & 3 & \\
\hline & & & 3 & & & 9.6 & \\
\hline & & & 5 & & & 16 & \\
\hline & 8.5 & 1.5 & 1 & & & 1 & \\
\hline & & & 3 & & & 6.6 & \\
\hline & & & 5 & & & 15 & \\
\hline \multirow[t]{3}{*}{2005} & 3.5 & 1.5 & 5 & 35,974 & 200 & 6.3 & Low \\
\hline & 6 & 1.5 & 5 & & & 6 & \\
\hline & 8.5 & 1.5 & 5 & & & 4 & \\
\hline
\end{tabular}

${ }^{\mathrm{z}}$ Total orchard production in kilograms per hectare.

incidence of FB injury was greater in fruit from the late harvest (starch index 6.0 compared with 3.5) in 2002 for the 1.5- and 3-kPa $\mathrm{O}_{2}$ atmospheres, and $\mathrm{FB}$ incidence was similar among harvests in 2003 and 2005 (Table 2). However, in 2004, FB incidence in fruit from the first harvest $(21.3 \%)$ was significantly higher than for the following harvests $(9.6 \%$ and $6.6 \%)$ in $1.5-\mathrm{kPa} \mathrm{O}_{2}$ and $3-\mathrm{kPa} \mathrm{CO}_{2}$ (Table 2). No change in FB incidence was observed between 2,4 , and 6 months of storage (data not shown), and fruit stored in air with $<0.05-\mathrm{kPa} \mathrm{CO}_{2}$ did not exhibit FB at any time, a pattern that was consistent among years.

EFFECT OF 1-MCP, DPA, AND DELAYEd CA. Treatment of fruit with 1-MCP before storage did not reduce the incidence of FB (data not shown), while DPA inhibited FB completely in three consecutive seasons. As an example, in 2004, $16 \%$ of fruit were affected with $\mathrm{FB}$ in $1.5-\mathrm{kPa} \mathrm{O}_{2}$ and $5-\mathrm{kPa} \mathrm{CO}_{2}$ without DPA treatment compared with $0 \%$ with DPA treatment. In addition, in 2004 , only a delay of 4 weeks in cold storage at $0.5^{\circ} \mathrm{C}$ before placing the apples in $\mathrm{CA}$ with $1.5-\mathrm{kPa} \mathrm{O}_{2}+5-\mathrm{kPa} \mathrm{CO}_{2}$ significantly decreased the incidence of $\mathrm{FB}$ after 4 months of storage, with $\approx 75 \%$ decrease in FB incidence compared with no delay before CA storage (Table 3). Fruit from the 4-week delay were significantly softer (4-N lower firmness in $3-\mathrm{kPa} \mathrm{CO}_{2}$ and 5$\mathrm{N}$ lower firmness in 5- $\mathrm{kPa} \mathrm{CO}_{2}$ ) than nondelayed fruit, while the 2week-delayed fruit had similar firmness as the nondelayed controls after 4 months storage (data not shown).

Mineral CONCENTRATion, Fruit Size, AND CROP LOAD. We observed the relationship between FB incidence each year and fruit mineral concentrations (Fig. 2). In 2003, fruit had a lower incidence of FB and had significantly higher $\mathrm{Mg}, \mathrm{B}$, and $\mathrm{Ca}$ concentrations and significantly lower concentration of $\mathrm{K}$ than in 2002 and 2004 when FB incidence was higher. However, the 2005 season also had low FB incidence but had the lowest Ca concentration of all seasons, lower $\mathrm{Mg}$ and $\mathrm{B}$, and higher $\mathrm{K}$. There was no relationship between $\mathrm{NO}_{3}^{-}, \mathrm{NH}_{4}{ }^{+}, \mathrm{Zn}, \mathrm{Fe}, \mathrm{Cu}, \mathrm{P}$, or $\mathrm{S}$ concentration and FB (data not shown). When individual apples were studied, $\mathrm{Ca}$ concentration in the flesh was significantly lower in apples stored in CA and damaged by FB than in undamaged apples stored under the same CA conditions [28.1 vs. $36.6 \mu \mathrm{g}$ Ca per gram fresh weight (FW)]. In 2003 and 2005 when the percentage of FB was low, fruit were large (183$200 \mathrm{~g}$ ) in comparison with an average fruit size of 173-176 g in 2002 and 2004 (Table 2). At the same time, in 2002 and 2004, when the percentage of FB was higher than in 2003 and 2005, the crop load was also higher (Table 2).

Seasonal weather. The incidence of FB in Pink Lady apple varied from season to season. For the intermediate-maturity harvest, the percentage of FB was as high as $14 \%$ in 2002 and as low as $1.3 \%$ in 2003 in CA with $3-\mathrm{kPa} \mathrm{CO}_{2}$ (Table 2). The CGDD $\geq 10{ }^{\circ} \mathrm{C}$ during the 50 DAFB were high in 2004, corresponding with high FB incidence, and low in 2003, corresponding with low FB incidence (Table 4). However, CGDD $\geq 10{ }^{\circ} \mathrm{C}$ during 50 DAFB was not well related to FB incidence in 2002 and 2005. The low-temperature exposure $\left(\mathrm{CDD}<10{ }^{\circ} \mathrm{C}\right)$ during 50 DAFB was highest in 2002, corresponding with high FB incidence; however, in 2004, 

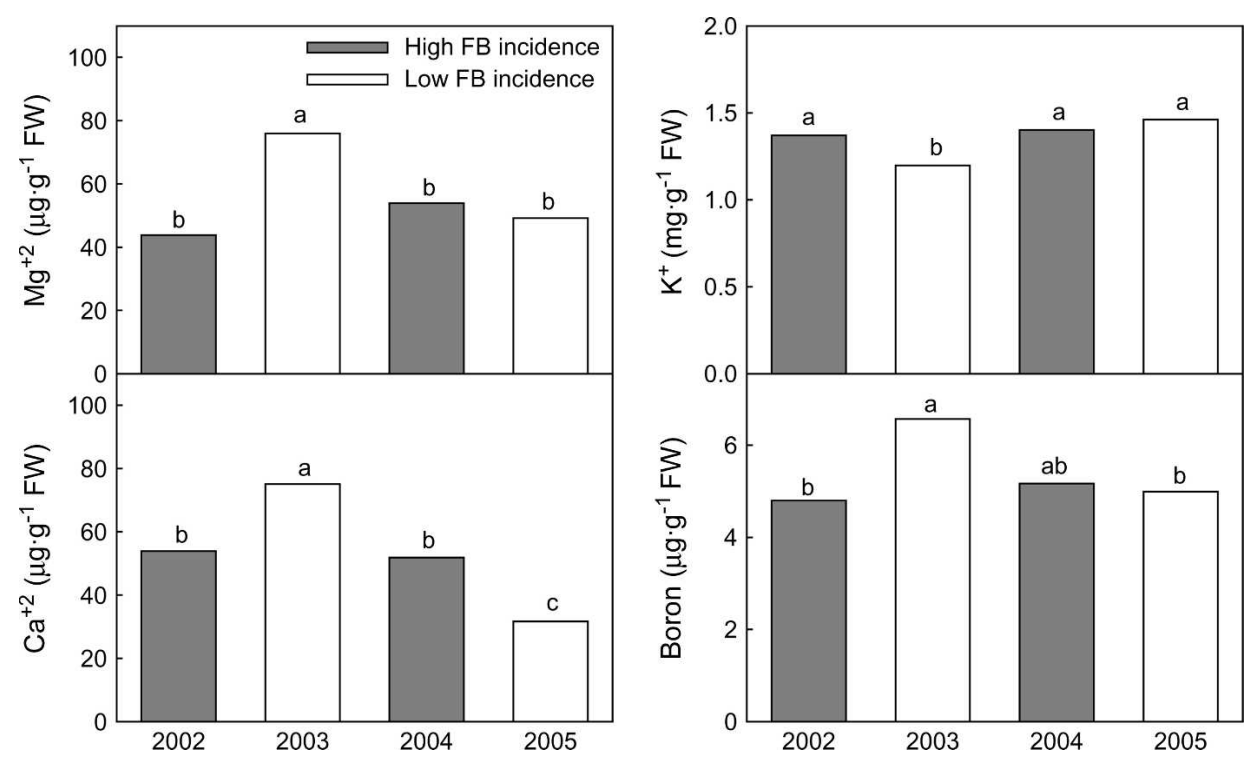

Fig. 2. Calcium, potassium, magnesium, and boron concentration ( $\mu \mathrm{g}$ or mg per gram fresh weight) in apples at harvest in 2002-2005. Different letters indicate significant differences within a mineral $(P \leq 0.05)$ according to Tukey's test; "High" and "Low" correspond to the severity of flesh browning incidence for that year. Starch index at harvest, $\approx 6.0$.

Table 3. Incidence (\%) of flesh browning in Pink Lady apples harvested at starch score 8.5 in 2004 after 4 mo. of storage in air or controlled atmosphere $\left(\mathrm{CO}_{2}\right.$ with $\left.1.5-\mathrm{kPa} \mathrm{O}_{2}\right)$ at $0.5^{\circ} \mathrm{C}$ preceded by a $0-, 2-$, or 4 -week delay in cold storage.

\begin{tabular}{lccc}
\hline \multicolumn{4}{c}{ Flesh browning incidence (\%) } \\
\hline & \multicolumn{3}{c}{ Delay in CA storage (weeks) } \\
\cline { 2 - 4 } $\mathrm{CO}_{2}(\mathrm{kPa})$ & 0 & 2 & 4 \\
\hline 1 & $1 \mathrm{~cd}$ & $0 \mathrm{~d}$ & $0 \mathrm{~d}$ \\
3 & $5 \mathrm{bc}$ & $3 \mathrm{~cd}$ & $4 \mathrm{bcd}$ \\
5 & $13 \mathrm{a}^{\mathrm{z}}$ & $8 \mathrm{~b}$ & $3 \mathrm{~cd}$
\end{tabular}

${ }^{\mathrm{z}}$ Different letters within a row indicate significant differences $(P \leq$ 0.05 ) according to Tukey's test.

Table 4. Relationship between browning severity of Pink Lady apple flesh and cumulative growing degree days (CGDD) $\geq 10^{\circ} \mathrm{C}$ and low-temperature exposure [cumulative degree days (CDD) $<$ $10{ }^{\circ} \mathrm{C}$ ] for the $50 \mathrm{~d}$ after full bloom and the density of the fruit at harvest in 2002-2005.

\begin{tabular}{lcccc}
\hline Season & $\begin{array}{c}\text { Flesh } \\
\text { browning } \\
\text { severity }\end{array}$ & $\begin{array}{c}\text { CGDD } \\
\geq 10^{\circ} \mathrm{C}\end{array}$ & $\begin{array}{c}\text { Low-temp. } \\
\text { exposure } \\
\left(\mathrm{CDD}<10^{\circ} \mathrm{C}\right)\end{array}$ & $\begin{array}{c}\text { Density at } \\
\text { harvest } \\
\left(\mathrm{kg} \cdot \mathrm{L}^{-1}\right)\end{array}$ \\
\hline 2002 & High & 178 & 17.3 & $0.822 \mathrm{a}^{\mathrm{z}}$ \\
2003 & Low & 156 & 2.4 & $0.797 \mathrm{~b}$ \\
2004 & High & 322 & 0.0 & $0.802 \mathrm{~b}$ \\
2005 & Low & 178 & 1.6 & $-\mathrm{y}$
\end{tabular}

${ }^{\mathrm{z}}$ Different letters indicate significant differences $(P \leq 0.05)$ according to Tukey's test.

${ }^{y}$ No data collected.

another season with high FB incidence, low-temperature exposure was very low.

We also determined the CGDD $\geq 10{ }^{\circ} \mathrm{C}$ from 1 May to harvest. Season 2003 presented the highest CGDD $\geq 10{ }^{\circ} \mathrm{C}$ accumulation for every harvest, corresponding with a low incidence of FB (Table 5). The CGDD $\geq 10^{\circ} \mathrm{C}$ measured from 1 May to 31 Oct. (average commercial harvest date) were also higher in 2003 than the 7-year average from 1998 to 2005 . However, the 2005 season, which also had a low incidence of FB, had intermediate $\mathrm{CGDD} \geq 10^{\circ} \mathrm{C}$.

\section{Discussion}

Our results show that $\mathrm{CO}_{2}$ induced FB was strongly associated with the $\mathrm{CO}_{2}$ concentration in storage. A low concentration of $\mathrm{O}_{2}$ increased the incidence of the disorder, but $21-\mathrm{kPa} \mathrm{O}_{2}$ did not prevent it when $\mathrm{CO}_{2}$ was elevated. These results agree with Watkins et al. (1997), Lau (1998), and Volz et al. (1998), who proposed that the incidence of FB and external browning were greater with higher $\mathrm{CO}_{2}$ concentration. However, other factors appear to modulate fruit susceptibility, as we can conclude from the differences in incidence of FB among seasons.

In 2002, there was a trend toward more FB in the lateharvested than in the early-harvested fruit. On the contrary, in 2004, fruit from the earliest harvest had higher FB incidence. The pattern of 2004 in our study seems contradictory to previously reported trends by Volz et al. (1998) and Lau (1998) in which more mature fruit would show higher FB incidence. Both groups found that delaying harvest generated a higher incidence of FB and internal cavities (IC) in 'Fuji' and 'Braeburn' apples, respectively. Lau (1998) attributed this to an increase in respiration rate, skin resistance, and sensitivity to low $\mathrm{O}_{2}$ and elevated $\mathrm{CO}_{2}$ atmospheres in the late-harvested fruit compared with the early-harvested fruit. However, Elgar et al. (1999) found that early-harvested 'Braeburn' apples showed a higher incidence of internal cavities than the delayed-harvest fruit. Additionally, Smock and Blanpied (1963) and Meheriuk (1977) associated higher levels of external $\mathrm{CO}_{2}$ injury with earlier harvests.

DPA completely inhibited $\mathrm{CO}_{2}$ injury. Others have also shown that this antioxidant can inhibit $\mathrm{CO}_{2}$-induced external

Table 5. Relationship between incidence of flesh browning in Pink Lady apples and cumulative growing degree days (CGDD) $\geq 10^{\circ} \mathrm{C}$ for the period 1 May to harvest for each of the harvests and for the period 1 May-31 Oct. (average time for last harvest) in 2002-2005 and the average value for 1998-2005.

\begin{tabular}{|c|c|c|c|c|c|}
\hline \multirow[b]{2}{*}{$\mathrm{Yr}$} & \multirow[b]{2}{*}{ FB incidence } & \multicolumn{3}{|c|}{$\begin{array}{c}1 \text { May-harvest } \\
\left(\mathrm{CGDD} \geq 10^{\circ} \mathrm{C}\right)\end{array}$} & \multirow{2}{*}{$\begin{array}{c}1 \text { May-31 Oct. } \\
\left(\mathrm{CGDD} \geq 10^{\circ} \mathrm{C}\right) \\
\mathrm{H} 3\end{array}$} \\
\hline & & $\mathrm{H} 1$ & $\mathrm{H} 2$ & $\mathrm{H} 3$ & \\
\hline 2002 & High & 1571 & 1609 & $-\mathrm{y}$ & 1838 \\
\hline 2003 & Low & 1820 & 1940 & 2004 & 2004 \\
\hline 2004 & High & 1605 & 1732 & 1831 & 1846 \\
\hline 2005 & Low & 1634 & 1738 & 1828 & 1842 \\
\hline 7-Year avg ${ }^{z}$ & & & & & 1923 \\
\hline
\end{tabular}

${ }^{\mathrm{z}}$ Average value for $1998-2005$.

${ }^{\mathrm{y}}$ No third harvest in 2002. 
and internal browning as well as storage scald in stored apples (Fernández-Trujillo et al., 2001; Lau, 1990; Watkins et al., 1997). Delaying the introduction of CA in cold storage has also been shown to reduce $\mathrm{CO}_{2}$ injury, both externally (Watkins et al., 1997) and internally (Argenta et al., 2000; Colgan et al., 1999). The reduction in damage was not seen until the delay was longer than 5 or 6 weeks for external or internal injury, respectively, for Watkins et al. (1997) and Argenta et al. (2000), although in 'Fuji' a 4-week delay has been shown to eliminate $\mathrm{CO}_{2}$-induced FB (R.K. Volz and E.J. Mitcham, unpublished data). For Pink Lady, we observed a significant reduction in $\mathrm{CO}_{2}$ injury after a 4-week delay in CA with 5-kPa CO 2 . Perhaps this cold period before $\mathrm{CA}$ storage allows for a reduction in respiration rates, stabilization of membranes, and production of ascorbic acid after the stress of harvest in which the fruit is separated from the tree, its main source of nutrients. Firmness of Pink Lady apples that were held in cold storage for 4 weeks before CA storage was lower than that of apples placed directly in $\mathrm{CA}$ with $1.5-\mathrm{kPa} \mathrm{O}_{2}$ plus 3- or 5-kPa $\mathrm{CO}_{2}$. After 5 months in CA, Watkins et al. (1997) and Argenta et al. (2000) found that 'Empire' and 'Fuji' apples were softer following 8 months of storage when they were delayed 2-12 weeks in air before CA than when they were placed directly in CA. Treating apples after harvest with 1-MCP did not have any effect on FB incidence. The FB disorder does not appear to be associated with ethylene action.

During the first three seasons of this study, a relationship between the concentrations of $\mathrm{Ca}, \mathrm{Mg}, \mathrm{K}$, and $\mathrm{B}$ and $\mathrm{FB}$ incidence was observed. While there appeared to be a trend with high $\mathrm{Mg}^{2+}, \mathrm{Ca}^{2+}$, and $\mathrm{B}$ and low $\mathrm{K}^{+}$related to low $\mathrm{FB}$ incidence in 2002, 2003, and 2004, this relationship did not hold in 2005. Lau and Looney (1978) investigated differences in mineral concentration of 'Golden Delicious' apples and found a greater incidence of $\mathrm{CO}_{2}$ injury associated with higher fruit $\mathrm{N}, \mathrm{Mn}$, and $\mathrm{Zn}$ and lower $\mathrm{K}$ and $\mathrm{Mg}$, but no association with $\mathrm{Ca}$ concentrations. Low $\mathrm{Ca}$ concentrations have long been recognized to increase the susceptibility of apple fruit to physiological disorders (Ferguson and Watkins, 1992). However, in 2005, apples had the lowest $\mathrm{Ca}$ and $\mathrm{B}$ concentrations of all four seasons, but the incidence of FB was also low. This result may indicate that high $\mathrm{Ca}$ can reduce the susceptibility to FB, such as in 2003, but low Ca concentration does not necessarily lead to high susceptibility to the disorder. We saw a similar pattern with $\mathrm{Mg}$ and the opposite pattern with $\mathrm{K}$. When we investigated the mineral concentration of individual apples, those apples with FB after storage were the apples with lower $\mathrm{Ca}$ concentration. The relationship of $\mathrm{Ca}$ with $\mathrm{CO}_{2}$-induced $\mathrm{FB}$ remains uncertain. High concentration of $\mathrm{Ca}$ appears to reduce the susceptibility of the apple to the disorder; however, $\mathrm{Ca}$ alone does not explain all the variability we have observed among seasons.

Fruit from light cropping seasons are more susceptible to postharvest disorders, like BBD (Elgar et al., 1999), but in our study lower crop-load years resulted in low FB incidence, and seasons with higher crop load had high FB incidence. There appears to be a biennial pattern to FB susceptibility in our study, with 2002 and 2004 being the years of more severe FB incidence and highest crop loads. Kondo (1992) reported that overcropping treatments reduced significantly the content of ascorbic acid. Ascorbic acid content has been related to FB incidence in fruit (de Castro et al., unpublished data), and this may explain why high crop-load years will present a high FB incidence.
Light crop loads have been associated with higher density fruit than fruit from trees with more commercial-sized crop loads (Bussakorn et al., 2001). However, in our study we found that the average fruit density in 2003, a light-cropped year, was similar to the average in 2004, the highest crop-load year, In addition, fruit density was not related with FB incidence in our study.

Low- or high-temperature exposure during the first 50 DAFB does not seem to be related with the seasonal pattern in FB. The high amount of chilling 50 DAFB in 2002 might explain the high severity of FB incidence; however, in 2004, the other season with high FB severity, low-temperature exposure was low.

The climate during the growing season seems to influence FB susceptibility. Our results agree with previous studies that found a relationship between cool growing seasons (May to harvest) and increased incidence of BBD (Lau, 1998). Lau concluded that a total number of $\mathrm{CGDD} \geq 10{ }^{\circ} \mathrm{C}$ less than 1300 resulted in an increased incidence of internal browning. For our trial with Pink Lady, it is difficult to propose a specific threshold number; however, it is clear that 2002, with the lowest number of $\mathrm{CGGD} \geq 10{ }^{\circ} \mathrm{C}$ had high $\mathrm{FB}$ incidence and 2003 , the year with largest number of CGDD $\geq 10^{\circ} \mathrm{C}$, had the lowest incidence of FB. However, 2005 was nearly as low as 2002 in CGDD $\geq 10^{\circ} \mathrm{C}$ but had low FB incidence.

It is clear that fruit susceptibility to FB cannot be related to a single condition before harvest or during storage. High $\mathrm{CO}_{2}$ concentration is the main factor causing FB; however, its effect is modulated by a number of known-and not yet knowninteracting factors. Among these factors, harvest date, mineral nutrition, and seasonal weather conditions have shown some relationship with apple fruit susceptibility to high- $\mathrm{CO}_{2}-$ induced FB and warrant further study.

\section{Literature Cited}

Argenta, L., X. Fan, and J. Mattheis. 2000. Delaying establishment of controlled atmosphere or $\mathrm{CO}_{2}$ exposure reduces 'Fuji' apple $\mathrm{CO}_{2}$ injury without excessive fruit quality loss. Postharvest Biol. Technol. 20:221-229.

Bramlage, W.J., M. Drake, and W.J. Lord. 1980. The influence of mineral nutrition on the quality and storage performance of pome fruits grown in North America, p. 29-39. In: D. Atkinson, J.E. Jackson, R.O. Sharples, and W.J. Waller (eds.). Mineral nutrition of fruit trees. Butterworths, Sevenoaks, Kent, England.

Bramlage, W.J. and S. Meir. 1990. Chilling injury of crops of temperate origin, p. 37-49. In: C.Y. Wang (ed.). Chilling injury of horticultural crops. CRC Press, Boca Raton FL.

Bussakorn, S.M., M.H. Behboudian, and S. Ganesh. 2001. Fruit quality attributes and their interrelationships of 'Braeburn' apple in response to deficit irrigation and to crop load. Gartenbauwissenschaft 66: 247-253.

Colgan, R.J., C.J. Dover, D.S. Johnson, and K. Pearson. 1999. Delayed $\mathrm{CA}$ and oxygen at $1 \mathrm{kPa}$ or less control superficial scald without $\mathrm{CO}_{2}$ injury on Bramley's Seedling apples. Postharvest Biol. Technol. 16:223-231.

Cripps, J.E.L., L.A. Richards, and A.M. Mairata. 1993. 'Pink Lady' apple. HortScience 28:1057.

de Villiers, G.D.B. 1961. The effect of weather and climate upon the keeping quality of fruit. Working Group Report, Commission for Agricultural Meteorology, World Meteorological Organization, Geneva, Switzerland.

Elgar, H.J., D.M. Burmeister, and C.B. Watkins. 1998. Storage and handling effects on a $\mathrm{CO}_{2}$ related internal browning disorder of 'Braeburn' apples. HortScience 33:719-722. 
Elgar, H.J., C.B. Watkins, and N. Lallu. 1999. Harvest date and crop load effects on a carbon dioxide-related storage injury of 'Braeburn' apple. HortScience 34:305-309.

Ferguson, I.B. and C.B. Watkins. 1992. Crop load affects mineral concentrations and incidence of bitter pit in 'Cox's Orange Pippin' apple fruit. J. Amer. Soc. Hort. Sci. 117:373-376.

Fernández-Trujillo, J.P., J.F. Nock, and C.B. Watkins. 2001. Superficial scald, carbon dioxide injury, and changes of fermentation products and organic acids in 'Cortland' and 'Law Rome' apples after high carbon dioxide stress treatment. J. Amer. Soc. Hort. Sci. 126:235-241.

Kondo, S. 1992. Effect of environmental conditions on the contents of sugar and ascorbic acid in Shensu apple fruit. J. Jpn. Soc. Food Sci. Technol. 39:1112-1118.

Lau, O.L. 1990. Efficacy of diphenylamine, ultra-low oxygen and ethylene scrubbing on scald control in 'Delicious' apples. J. Amer. Soc. Hort. Sci. 115:959-961.

Lau, O.L. 1998. Effect of growing season, harvest maturity, waxing, low $\mathrm{O}_{2}$ and elevated $\mathrm{CO}_{2}$ on flesh browning disorders in 'Braeburn' apples. Postharvest Biol. Technol. 14:131-141.

Lau, O.L. and N. Looney. 1978. Effects of prestorage high $\mathrm{CO}_{2}$ treatment on British Columbia and Washington State 'Golden Delicious' apples. J. Amer. Soc. Hort. Sci. 103:341344.

Marinos, N.G. 1962. Studies on submicroscopic aspects of mineral deficiencies. I. Calcium deficiency in the shoot apex of barley. Amer. J. Bot. 49:834-841.

Meheriuk, M. 1977. Treatment of Golden Delicious apples with $\mathrm{CO}_{2}$ prior to CA storage. Can. J. Plant Sci. 57:467-471.
Meyer, G.A. and P.N. Keliher. 1992. An overview of analysis by inductively coupled plasma-atomic emission spectrometry, p. 473-505. In: A. Montaser and D.W. Golightly (eds.). Inductively coupled plasmas in analytical atomic spectrometry. VCH Publishers, New York. Parr, A.J. and B.C. Loughman. 1983. Boron and membrane function in plants, p. 87-107. In: D.A. Robb and W.S. Pierpoint (eds.). Metals and micronutrients: uptake and utilization by plants. Academic Press, London.

Sharples, R.O. 1980. The influence of orchard nutrition on the storage quality of apples and pears grown in the U.K., p. 17-28. In: D. Atkinson, J.E. Jackson, R.O. Sharples, and W.M. Waller (eds.). Mineral nutrition of fruit trees. Butterworths, London.

Smock, R.M. and G.D. Blanpied. 1963. Some effects of temperature and rate of oxygen reduction on the quality of controlled atmosphere stored McIntosh apples. Proc. Amer. Soc. Hort. Sci. 83:135-138.

Volz, R.K., W.V. Biasi, J.A. Grant, and E.J. Mitcham. 1998. Prediction of controlled atmosphere-induced flesh browning in 'Fuji' apple. Postharvest Biol. Technol. 13:97-107.

Warrington, I.J., T.A. Fulton, E.A. Halligan, and H.N. de Silva. 1999. Apple fruit growth and maturity are affected by early season temperatures. J. Amer. Soc. Hort. Sci. 124:468-477.

Watkins, C.B., K.J. Silsby, and M.C. Goffinet. 1997. Controlled atmosphere and antioxidant effects on external $\mathrm{CO}_{2}$ injury of Empire apples. HortScience 32:1242-1246.

Wilkinson, B.G. and J.C. Fidler. 1973. Physiological disorders, p. $65-$ 131. In: J.C. Fidler, B.G. Wilkinson, K.L. Edney, and R.O. Sharples (eds.). The biology of apple and pear storage. Research Review No. 3. Commonwealth Bureau of Horticulture and Plantation Crops, East Malling, Kent, England. 